\title{
Molecular Bases and Genotyping for Rare Blood Types
}

\author{
Christof Jungbauer \\ Blutspendezentrale für Wien, Niederösterreich und Burgenland, Österreichisches Rotes Kreuz, Wien, Austria
}

\section{Key Words}

Blood supply · Genotyping · Molecular blood group typing $\cdot$ Red blood cell antigens

\section{Summary}

The provision of suitable blood units for patients carrying clinically significant antibodies to high-frequency antigens (HFAs) is a special challenge for blood establishments. Typing of donors and screening for HFA-negative individuals is increasingly performed by genotyping. In this context the selection of the HFAs of interest, the molecular background of some model antigens, and the different requirements for donor screening versus resolving serological problems are addressed. In addition, several published approaches for mass-scale donor genotyping are reviewed. Furthermore, the results of a DNA-based donor screening for 12 HFAs in 11,400 Austrian donors that resulted in finding 94 newly identified HFA-negative donors are referred to.

\section{Introduction}

An important concern of blood establishments is the supply of suitable blood units for carriers of irregular red blood cell (RBC) antibodies. In general, the clinical supply of fitting $\mathrm{RBC}$ units for most patients with RBC alloantibodies is adequate. In patients with clinically significant antibodies to highfrequency antigens (HFAs; antigen prevalence > 99\%) the blood supply can be more critical. It was shown that one third of these patients do not get sufficient numbers of blood units in time [1]. For provision of compatible blood for these cases, blood establishments or organizations apply different propri-

\section{Schlüsselwörter}

Blutversorgung · Genotypisierung · Molekulare Blutgruppentypisierung · Erythrozytenantigene

\section{Zusammenfassung}

Die Blutversorgung von Patienten mit Antikörpern gegen klinisch relevante hochfrequente Antigene (HFAs) ist eine besondere Herausforderung für transfusionsmedizinische Zentren. Zunehmend wird für die Typisierung der Blutspender und die Suche nach HFA-negativen Individuen auch die Genotypisierung eingesetzt. In diesem Kontext wird auf die Auswahl der relevanten HFAs, die molekularen Grundlagen einiger ausgesuchter Antigene und die Unterschiede zwischen Spender-Screening und Patientenabklärung eingegangen. Einige publizierte Verfahren zur "Mass-scale»-Spendertypisierung werden im Überblick gezeigt. Außerdem wird über die Ergebnisse eines DNA-basierten Spender-Screenings bei 11400 österreichischen Blutspendern auf das Vorliegen von 12 HFAs berichtet, bei dem auch 94 neue seltene Spender identifiziert werden konnten.

etary typing programs and are interconnected with national and international donor panels and panels of frozen blood.

The definition of rare blood or a rare donor has not yet been harmonized. In most countries a blood donor is considered as rare if the phenotype that is lacking can be found in a population in 1:1,000 or less [2]. However, this frequency is an approximate value as the in-time supply of antigen-negative units of higher prevalence (e.g. k-1:500) can also be a challenge. Besides lacking an HFA, a second category of rare donors or phenotypes is negativity in a combination of antigens for the blood supply of patients with multiple alloantibody specificities (often involving $\mathrm{Rh}$ antigens).

\begin{tabular}{ll}
\hline KARGER & $\oplus$ 2009 S. Karger GmbH, Freiburg \\
Fax +497614520714 & Accessible online at: \\
Information@Karger.de & www.karger.com/tmh \\
www.karger.com &
\end{tabular}


The importance of certain HFAs for the provision of patients depends on the rate to induce alloimmunization, their prevalence in a discrete population, and the clinical significance of the alloantibody. As the allele distribution can differ widely in some populations, there are special needs in different regions of the world. For example, the data of the rare blood supplied in France during a 14-year period from 1994 to 2008 showed demand for: Fy(a-b-) (26.1\%), k- (19.4\%), Yt(a-) $(12.7 \%)$, r'r' $(9.1 \%)$, U- (7.0\%), Vel- (5.6\%), r'r' $(3.5 \%)$, Lu(b-) (3.2\%), D- - (1.1\%), Lu:-13 (0.9\%), Js(b-) (0.9\%), $\mathrm{Kp}(\mathrm{b}-)(0.9 \%), \mathrm{R}_{\mathrm{z}} \mathrm{R}_{\mathrm{z}}(0.7 \%), \mathrm{I}-(0.5 \%), \mathrm{O}_{\mathrm{h}}(0.4 \%)$ and $\mathrm{Ge}:$ $-2.3(0.3 \%)$ [2]. Nevertheless, there were shortages in availability for the provision of some types specifically found in the African-Caribbean population (U- D-, $\mathrm{hr}^{\mathrm{S}}-, \mathrm{Hr}^{\mathrm{B}}-, \mathrm{Js}(\mathrm{b}-)$ and $\left.\mathrm{R}^{\mathrm{N}} / \mathrm{R}^{\mathrm{N}}\right)$. The HFA antibody incidence in Germany, Switzerland, and Austria was studied during a 20-month period [1]. The HFA antibody specificities were directed against: $\mathrm{Kp}^{\mathrm{b}}$ (19.6\%), Vel (17.9\%), Lu ${ }^{\mathrm{b}}(14.3 \%), \mathrm{Yt}^{\mathrm{a}},(14.3 \%), \mathrm{Co}^{\mathrm{a}}(5.4 \%)$, $\mathrm{H}(5.4 \%), \mathrm{AnWj}(3.6 \%), \mathrm{Kx}(3.6 \%)$, MAM (3.6\%), Fy3 (1.8\%), Ku (1.8\%), Lan (1.8\%), Lu6 (1.8\%), Rh17 (1.8\%) and Tja (PP1Pk; $1.8 \%$ ). $66 \%$ of the rare blood supply involved the four specificities anti-Kp ${ }^{\mathrm{b}}$, anti-Vel, anti-Lu ${ }^{\mathrm{b}}$, or anti-Yta ${ }^{\mathrm{a}}$. These exemplary data represent the regional aspect in the need for rare blood and indicate that screening for the 'most needed' rare blood groups differs from region to region. In an international comparative survey it was concluded that in general $\mathrm{K}_{0}$, McLeod, p, U-, Lan-, Vel-, and Ge:-2,-3 are probably the most difficult phenotypes to find [2].

To ensure the appropriate blood supply for patients with $\mathrm{RBC}$ antibodies, blood centers commonly phenotype a subset of their repeated donors, beside the $\mathrm{ABO}, \mathrm{Rh}$ phenotype and $\mathrm{K}$ antigen, also for a lager set of 'minor' $\mathrm{RBC}$ antigens and especially for negativity in some important HFAs. A sufficient stock of pre-typed donors in the databases enables a short response time for the provision of the blood units requested and prevents acute on-demand typing with an unpredictable hit rate.

Carrying out additional typing procedures is costly and time-consuming. Besides, serological methods are limited by the availability of reagents or antisera and their quality (e.g. weakly reactive antisera: anti-Do ${ }^{\mathrm{a}}$, anti-Do ${ }^{\mathrm{b}}$, anti-Js ${ }^{\mathrm{a}}$, anti-Js ${ }^{\mathrm{b}}$ ). Especially for screening of many HFAs, blood centers often have to use patients' sera to identify antigen-negative donors. If available, regulated reagents are used for confirmation of the screening test results.

As an alternative to conventional phenotyping, a vast number of DNA-based assays, which are feasible for highthroughput RBC donor typing, was established during the last years.

\section{Genotyping of RBC Antigens}

Today most of RBC antigen polymorphisms are known on allelic level. The information can be obtained by dbRBC $w w w$. ncbi.nlm.nih.gov/gv/mhc/xslcgi.cgi?cmd = bgmut/home [3].

This has enabled the development of DNA-based molecular biology assays for determination of the corresponding antigen phenotype.

The decision for a certain assay or technical platform and the feasibility of genotyping and correctness of the results may be influenced by the following factors:

- primary goal and special requirements the application was chosen for,

- genetic complexity at a locus and number of alleles or genotypes that should be detected by the assay,

- level of knowledge about alleles involved and distribution in certain populations,

- technical aspects regarding feasibility of primer/probe binding site selection and their specificity.

Choosing a suitable method and awareness of its limitations will allow acceptable accuracy of the test results, especially if applied for common alleles and well-examined ethnic populations. It has to be taken into consideration that many unknown alleles are found every year or that, for example, genes can easily be disrupted by mutations (e.g. frame shift), almost regardless of the position in the exons of the genes, giving rise to yet unknown causes of null types.

Therefore, each application has special requirements depending on the primary intention of the test: resolving serological discrepancies in the Rh system [4-6] the most complex system involving 2 homologous genes and almost 200 known alleles, requires much more effort and a different approach than, for example, simply screening for alleles in an apparently biallelic single nucleotide polymorphism (SNP) situation (e.g. $\mathrm{Yt}^{\mathrm{a}} / \mathrm{Yt}^{\mathrm{b}}$ ).

For the screening of HFA-negative blood donors, focusing on the most frequent alleles can be satisfactory. Every newly identified HFA-negative donor will subsequently undergo serological confirmation testing. Rare causes for HFA antigen negativity (e.g. null type) do not necessarily have to be included in the examination. In this respect donor genotyping for the most common causes of negativity in the HFAs $\left(\mathrm{k}, \mathrm{Kp}^{\mathrm{b}}\right.$, $\mathrm{Lu}^{\mathrm{b}}, \mathrm{Yt}^{\mathrm{a}}, \mathrm{Co}^{\mathrm{a}}$, etc.) can easily be achieved. In this case testing for a small number of alleles reveals the essential information. Hence, there are many different technical methods, including conventional and real-time PCR, that may be suitable for this application.

In contrast, genotyping of variant antigens that are caused by multiple alleles (e.g. Rh) or resolving discrepancies in a complex genetic environment are model applications for technical platforms that are supportive for multi-allele detection (e.g. array techniques in BloodGen ${ }^{\mathrm{TM}}$ and HEA BeadChip ${ }^{\mathrm{TM}}$ (BioArray Solutions, Warren, NJ, USA)). Table 1 shows a 
Table 1. Selection of recent publication on high-throughput RBC genotyping including HFAs

\begin{tabular}{|c|c|c|c|c|c|}
\hline $\begin{array}{l}\text { Number of RBC } \\
\text { genotype/allels included }\end{array}$ & HFA included & Technique & Study size, $\mathrm{n}^{\$}$ & Concordance rate, $\%$ & Reference \\
\hline 18 & LU2, KEL2, KEL4, DI2 & microarray & $372 *$ & $98-100$ & [7] \\
\hline 16 & KEL2, KEL4 & microarray & 618 & $97-100$ & [8] \\
\hline 35 & $\begin{array}{l}\text { LU2, KEL2, FY0, LW5, DI2, CO1, } \\
\text { DO4, DO5, SC1 }\end{array}$ & microarray & 188 & 100 & {$[9]$} \\
\hline$\#$ & MNS5, KEL2, KEL4, DO5 & microarray & 94 & \# & {$[10]$} \\
\hline $33,87,9,31^{\S}$ & \# & microarray & $1,000^{\pi}$ & $99.8^{\pi}$ & [11] \\
\hline 16 & LU2, KEL2, KEL4, KEL7, DI2, CO1 & microarray & 92 & 100 & [12] \\
\hline 17 & LU2, KEL2, CO1 & real-time PCR & 200 & 100 & [13] \\
\hline
\end{tabular}

${ }^{\S}$ Evaluation of defined samples.

*For most of the SNPs tested.

${ }^{\S} \mathrm{ABO}, \mathrm{RHD}, \mathrm{RHCE}$, minor antigens

"Not specified for the tests on RBC polymorphisms.

${ }^{\pi}$ Data from the Conformité Européenne (CE) submission www.progenika.com/eu/.

selection of publications on high-throughput genotyping with HFA included.

Variation causing blood group polymorphisms can be based on a variety of different genetic mechanisms $[5,14]$. The majority of blood groups are induced by SNPs (e.g. k/K, Kp $/ \mathrm{Kp}^{\mathrm{a}}$, $\left.\mathrm{Js}^{\mathrm{a}} / \mathrm{Js}^{\mathrm{b}}\right)$. Single nucleotide exchanges in the genes either cause immunogenic amino acid substitutions in proteins that directly define the blood groups or they can affect the specificity or function of a glycosyltransferase. In this case the antigenicity results from variant glycosylation (such as the ABO or globoside antigens). Some others polymorphisms are caused by small insertions or deletions (e.g. ABO O1 allele). Several different types of genetic variations have contributed to the complexity in the RH system. A deletion of the whole RHD gene is the common cause for the $\mathrm{RhD}$-negative phenotype in Caucasians while the latter or a $\mathrm{RhD}$ pseudogene can be found in the African population. Single nucleotide polymorphisms code for various $\mathrm{Rh}$ antigens $(\mathrm{C} / \mathrm{c}, \mathrm{E} / \mathrm{e}, \mathrm{Cw} / \mathrm{Cx} / \mathrm{MAR}$, etc.). Other phenotypes originate by missense mutations, nonsense mutations, deletion, and many RHD-RHCE-hybrid gene formations (e.g. DVI, DHAR, DBT). Modified gene expression can be caused by splice site mutations at the exon-intron junction (some Del). Null types of different blood group systems can also be based on diverse mechanisms. Often the gene is disrupted by a mutation (e.g. frame shift caused by base insertion or deletion) within the exons. A different mechanism is the silencing mutation in the FY promoter GATA motif -33C [15]. Another special reason for $\mathrm{a} \mathrm{Lu}(\mathrm{a}-\mathrm{b}-)$ (dominant type) is an inhibitory gene $\operatorname{In}(\mathrm{LU})$ that is silencing the LU expression. And beside this dominant $\operatorname{In}(\mathrm{LU})$ type two other causes (X-linked type and the recessive amorphous type) for the rare $\mathrm{Lu}(\mathrm{a}-\mathrm{b}-)$ phenotype are known [16-19].

Not all of the HFAs of clinical interest have been characterized on DNA level yet. Without knowledge of the DNA polymorphisms a genotyping approach is not feasible. If the antigens do not have an obvious relationship to an existing, well-characterized blood group, the HFAs are either placed in collections (e.g $211 \mathrm{Vel}$ ) or the 901 series of high-incidence antigens, which at present consists of the antigens Lan, $\mathrm{At}^{\mathrm{a}}, \mathrm{Jr}^{\mathrm{a}}, \mathrm{Emm}$, and AnWj. Details on criteria of the ISBT Committee on Terminology for Red Cell Surface Antigens and the current classification of RBC antigens can be found on http://blood.co.uk/ibgrl.

\section{Molecular Basis of Some Model High Prevalence Genotypes}

\section{$R H$}

The RH system is genetically the most complex blood group system [4-6, 14]. It is only comparable to the MNS system. It consists of two closely linked homologous genes (RHD, RHCE) at the RH locus in an arrangement that promotes genetic recombination and constitution of new antigens. 149 RHD alleles and 45 RHCE alleles have been reported so far. As mentioned above, a variety of genetic mechanisms is involved in the formation of $\mathrm{RH}$ alleles. There is a third homologous gene (RHAG) located on a different chromosome. It is coding for the Rh-associated glycoprotein (RhAG). Aberrant expression of RhAG on the cell surface is one cause for $\mathrm{Rh}_{\text {null }}$ (regulator type) or $\mathrm{Rh}_{\text {mod }}$ phenotypes.

As rare HFA negative donors $\left(\mathrm{Rh}_{\text {null }}\right.$ and rare $\mathrm{Rh}$ phenotypes) are identified by routine serology, genotyping for this application is mandatory.

\section{$M N S$}

The MNS system consists of 46 antigens. Except for M, N, S, $\mathrm{s}$, He and the high prevalence antigens $\mathrm{U}$ and several 'EN' antigens (EN = 'envelope'; e.g. En ${ }^{\mathrm{a}}$, ENEP), the majority of MNS antigens are low-prevalence antigens with a frequency of less than $1 \%$ in most populations $[5,14]$. The genomic back- 
ground of the MNS system is based on three genes in a gene cluster (GYPA, GYPB, and GYPE) sharing high homology in their sequence. GYPA is coding for glycophorin A (GPA), where the antigens $\mathrm{M}$ and $\mathrm{N}$ are located. The gene product of GYPB is glycophorin B (GPB) carrying the antigens $S$ and s. GYPE does not appear to be expressed on the normal RBC membrane, but is involved in gene rearrangements as cause of some variant (hybrid) alleles.

Antigens can be based on SNPs (e.g. S/s), hybrid genes, or deletions. A deletion of GYPB (exon 2 to 6) and GYPE (exon 1) results in the rare $U$ - phenotype [20].

\section{KEL and $X K$}

The Kell glycoprotein is expressing 31 antigens, including several high-prevalence antigens such as $\mathrm{k}, \mathrm{Kp}^{\mathrm{b}}, \mathrm{Js}^{\mathrm{b}}$ or $\mathrm{Ku}$ (which is absent in $\mathrm{K}_{0}$ people) [5, 21]. All KEL antigens rely on SNPs in the KEL gene. Kell protein expression can be either weakened as $\mathrm{K}_{\text {mod }}$ phenotype or is completely absent in $\mathrm{K}_{0}$ individuals [22-24]. (17 $\mathrm{K}_{0}$ alleles caused by e.g. premature stop codons, splice site mutations, or nucleotide substitutions have been described so far). Normal Kell protein expression depends on the integrity of the XK-KEL protein complex. Absence of $\mathrm{Kx}$, the public antigen on the XK protein, due to lack or mutation of the XK protein results in an attenuation of the KEL antigens, a McLeod phenotype.

\section{$F Y$}

The very few patients with alloanti-Fy3 require Fy(a- b-) blood. Fy $(a-b-)$ phenotypes can be caused by a silencing mutation in the erythroid FY gene promoter (GATA box $-33 \mathrm{~T}>\mathrm{C})[15,25]$. The Duffy glycoprotein is the receptor for some malarial parasites, and due to selective pressure this null type is frequent in the African population. Nevertheless, in this case usually $\mathrm{Fy}^{\mathrm{b}}$ is expressed in other tissues. Other rare causes for this phenotype that, in contrast to the GATA -33C mutation, allow alloimmunization to FY3 are based on different molecular mechanisms such as the creation of stop codons (due to single nucleotide mutations or a deletion in exon 2).

\section{$H$}

$\mathrm{H}$-deficient phenotypes are caused by mutations that disrupt the fucosyl-transferase 1 (FUT1) or the GDP-fucose transporter gene [5]. Two phenotypes are H-deficient: $\mathrm{O}_{\mathrm{h}}$ (Bombay) and Para-Bombay. Bombay people have an additional function loss of the FUT2 (non-secretor, se) gene product. In Para-Bombay there can either be the reduction or the total loss of $\mathrm{H}$ expression depending on the genotype. So far 40 alleles have been found to code for H-deficient phenotypes.

\section{$G L O B$}

The p phenotype (null type of the globoside blood group system) can be caused by a variety of mutations in the alpha 1,4 galactosyl transferase gene (A4GALT) [26-28]. The genetic background of the P1 and P2 phenotype could not be completely clarified so far [29].

\section{Genotyping of 11,418 Blood Donors for Twelve HFA}

The Austrian Red Cross Vienna Blood Center has been genotyped 11,418 donors with an in-house PCR assay using sequence-specific primers for $36 \mathrm{RBC}$ antigens, also including 12 HFAs. The results of this HFA screening subproject are described below. The entire technical protocol of the multiplex PCR screening for 36 genotypes will be published separately.

With regard to cost efficiency we decided to use a conventional PCR assay consisting of six reaction mixes for all 36 genotypes for one donor and up to seven genotypes multiplexed per reaction mix. Detection of PCR products was performed with agarose gel electrophoresis.

To enable high-throughput testing, the test system was end-to-end implemented in 96-well microplate format. The HFA genotypes included in the assay were: $L U 2\left(L u^{b}\right), L U 8$, KEL2 $(k), K E L 4\left(K p^{b}\right), K E L 7\left(J s^{b}\right), K E L 11, F Y, D I 2\left(D i^{b}\right)$, DI4 $\left(W r^{b}\right), Y T 1\left(Y t^{a}\right), I N 2\left(\operatorname{In}^{b}\right)$. ' $F Y^{\prime}$ in this respect is only limited to the absence of the FY0 erythroid promoter silencing (GATA -33C) allele.

\section{Material and Methods}

For genomic DNA extraction EDTA-anticoagulated blood samples of donors where obtained consecutively to the routine testing and consistent with our institute's guidelines. Genomic DNA extraction was performed using a Tecan RSP150 platform (Tecan, Männedorf, Switzerland) and QIAamp DNA Blood BioRobot 9604 Kit (Qiagen, Hilden, Germany).

For evaluation of the multiplex PCR assay for the included HFAs as many as available control blood or DNA samples were obtained and included in the validation process (e.g. 99 KEL2-negative samples). Typing standard was phenotyping with regulated reagents (if they were distributable).

The multiplex PCR assay is organized in six reaction mixes for a single blood donor containing 5-7 primer pairs (e.g. KEL2-PCR: KEL2-578C-r2 CTCATCAGAAGTCTCAGCG, $K E L-i 5-f 1$ CTAGAGGGTGGGTCTTCTTCC). The PCR products range from 209 to $713 \mathrm{bp}$. Primer mix number six, for example, consists of the PCRs for $F Y 2$ (product size: 712 bp), KEL3 (625 bp), JK2 (529 bp), MNS3 (397 bp), KEL2 (321 bp), MNS2 (260 bp), and DO2 (209 bp). Every primer mix contains at least one high-frequency genotype which is also used as an internal amplification control. The oligonucleotide mixes were aliquoted in ready-to-use concentrations on 96-well PCR reaction plates and were stored at $-20{ }^{\circ} \mathrm{C}$.

The PCR reaction was performed using GoTaq kit (Promega, Mannheim, Germany). Each reaction tube contained $0.75 \mathrm{U}$ Taq, $3 \mu \mathrm{l}$ of $5 \times$ PCR buffer, $2.5 \mu \mathrm{l}$ of $25 \mathrm{mmol} / 1 \mathrm{MgCl}_{2}$ solution ( $\left.4.17 \mathrm{nmol} / \mu \mathrm{l}\right), 0.33 \mathrm{mmol} / \mathrm{l}$ deoxynucleoside triphosphates (Applichem, Darmstadt, Germany), oligonucleotide primers, and $35 \mu \mathrm{g}$ of gDNA to a final reaction volume of $15 \mu 1$.

A GeneAmp ${ }^{\circledR}$ PCR System 9700 (Applied Biosystems) was used for the PCR.

The temperature profile started with $5 \mathrm{~min}$ at $94{ }^{\circ} \mathrm{C}$ followed by six cycles at $94{ }^{\circ} \mathrm{C}$ for $30 \mathrm{~s}, 67^{\circ} \mathrm{C}$ for $40 \mathrm{~s}$ (touch down for $0.5^{\circ} \mathrm{C}$ per cycle) and $72{ }^{\circ} \mathrm{C}$ for $50 \mathrm{~s}$. Subsequently 27 cycles at $94{ }^{\circ} \mathrm{C}$ for $30 \mathrm{~s}, 64{ }^{\circ} \mathrm{C}$ for $40 \mathrm{~s}$ and $72{ }^{\circ} \mathrm{C}$ for $50 \mathrm{~s}$ were added. The protocol ended with a final step at 72 ${ }^{\circ} \mathrm{C}$ for $2 \mathrm{~min}$.

Agarose Gel Electrophoresis

The PCR products were analyzed on $1.5 \%$ agarose gels. 
Table 2. Genotyping results for twelve high frequency antigens in 11,418 Austrian blood donors

\begin{tabular}{|c|c|c|c|c|c|c|c|c|c|c|c|c|}
\hline & LU2 & LU8 & KEL2 & KEL4 & KEL7 & KEL11 & FY* & DI2 & DI4 & YT1 & $\mathrm{CO} 1$ & IN2 \\
\hline Homozyous positive & 10,613 & 10,924 & 10,502 & 11,066 & 11,417 & 11,374 & 11,381 & 11,384 & 11,416 & 10,069 & 10,485 & 11,418 \\
\hline Heterozyous positive & 792 & 488 & 907 & 188 & 1 & 44 & 37 & 34 & 2 & 1312 & 906 & 0 \\
\hline Negative & 13 & 6 & 9 & 2 & 0 & 0 & 0 & 0 & 0 & 37 & 27 & 0 \\
\hline Indeterminate & 0 & 0 & 0 & 0 & 0 & 0 & 0 & 0 & 0 & 0 & 0 & 0 \\
\hline Number of tests & 11,418 & 11,418 & 11,418 & 11,256 & 11,418 & 11,418 & 11,418 & 11,418 & 11,418 & 11,418 & 11,418 & 11,418 \\
\hline Rate of negative individuals observed & 0.0011 & 0.0005 & 0.0008 & 0.0002 & 0.0000 & 0.0000 & 0.0000 & 0.0000 & 0.0000 & 0.0032 & 0.0024 & 0.0000 \\
\hline
\end{tabular}

*'FY' means negativity for the GATA -33C promoter silencing mutation.

\section{Results}

The multiplex PCR screening of 11,418 blood donors revealed 94 newly identified individuals lacking a high-prevalence antigen (table 2). All HFA-negative results were confirmed by serological tests (except for LU:-8 were no reagents were available). In $0.0014 \%$ of the amplificates the bands' fluorescence signal strength or the signal of the amplification control was not clearly determinable, and so the whole test including DNA extraction had to be repeated.

We also noticed a difference in allele distribution among blood donors and patients due to ethnic background. While only 37 out of 11,418 blood donors were heterozygous for the FY GATA -33C allele and no one homozygous, we found the allele with a 20 -fold higher frequency in our patient population. This could indicate that people of African origin are underrepresented in our donor population maybe due to exclusion of donors with an endemic malaria risk. As mentioned above, individuals with FY0 due to promoter silencing mutation do not form anti-Fy3 but rising of these alleles indicates that we also have to anticipate alloantibodies to rare blood types like U or KEL7 in the future.

\section{Discussion}

Many publications demonstrate that high-throughput donor genotyping for most relevant $\mathrm{RBC}$ antigens is feasible. Depending on the number of alleles that have to be tested, different technical platforms are suitable. It is entirely conceivable that in future mass genotyping of donors and patients will be performed with test systems detecting most of the known alleles in one procedure. Currently, technical platforms for this issue are microarray assays where thousands of alleles can be integrated. At the moment these tests are still quite expensive, and it has to be considered if the (comparably high) costs justify the additional information benefit in all applications (e.g. donor typing). With regard to cost efficiency, the Vienna Blood Center decided to screen for HFA-negative donors by conventional multiplex PCR.
The Vienna Blood Center had a lack of donors pre-typed for 'minor' RBC antigens for patients with RBC antibodies. Provision of suitable blood units caused acute typing efforts at unfavorable rates. Besides that, we noticed that the supply of antigen-negative blood units for $2 \%$ of the blood recipients caused approximately $20 \%$ of the overall costs of donor immunohematology. To decrease the rate of serological screening at the time of request, we were looking for a cost-efficient alternative to pre-type donors. Our calculations revealed that donor antigen typing by DNA screening in our setting was by far the cheapest method to add typing results to our antigen database.

Accuracy of genotyping results relies on genetic (e.g. complexity of the gene, gene expression or its suppression), technical (e.g. number of alleles involved, homologous genes, repetitive motives, suitable primer binding site), and knowledge-based (e.g. less investigated populations, allele prevalence) factors.

This has to be combined with the special assert for the DNA-based application. Does the situation require that the assay covers rare alleles, null types and splice-site mutations, or is focusing on a few SNPs satisfactory in this case? However, in donor screening antigens that are falsely typed as positive will not affect transfusion safety. Furthermore, antigens that were genetically predicted to be negative should always be confirmed using regulated serological reagents. Commonly two valid tests that have to be CE (Conformité Européenne) marked have to be applied.

With an increasing number of centers that routinely use molecular genetic technology for RBC typing, external quality assurance approaches are being required. The International Society of Blood Transfusion (ISBT) and the International Council for Standardization in Haematology (ICSH) organized international workshops on molecular blood genotyping [30]. A conclusion of the report points out that more standardization in nomenclature and in the usage of controls should be aimed at.

\section{Disclosure}

The author declared no conflict of interest. 


\section{References}

1 Seltsam A, Wagner FF, Salama A, Flegel WA: Antibodies to high-frequency antigens may decrease the quality of transfusion support: an observational study. Transfusion 2003;43:1563-1566.

2 Reesink HW, Engelfriet CP, Schennach H, et al: Donors with rare pheno (geno) type. Vox Sang 2008;95 236-253.

>3 Blumenfeld OO, Patnaik SK: Allelic genes of blood group antigens: a source of human mutations and cSNPs documented in the Blood Group Antigen Gene Mutation Database. Human Mutation 2004; 23:8-16.

4 Avent ND, Reid ME: The Rh blood group system: a review. Blood 2000;95:375-387.

5 Reid ME, Lomas-Francis C: Blood Group Antigen FactsBook, 2nd ed. San Diego, Academic Press, 2003.

6 Wagner FF, Flegel WA: Review: the molecular basis of the Rh blood group phenotypes. Immunohematology 2004;20:23-36.

7 Denomme GA, Van Oene M: High-throughput multiplex single-nucleotide polymorphism analysis for red cell and platelet antigen genotypes. Transfusion 2005;45:660-666.

8 Montpetit A, Phillips MS, Mongrain I, Lemieux R, St-Louis M: High-throughput molecular profiling of blood donors for minor red blood cell and platelet antigens. Transfusion 2006;46:841-848.

$\checkmark$ Hashmi G, Shariff T, Seul M, Vissavajjhala P, Hue-Roye K, Charles-Pierre D, Lomas-Francis C, Chaudhuri A, Reid M: A flexible array format for large-scale, rapid blood group DNA typing. Transfusion 2005;45:680-688.

10 Beiboer SH, Wieringa-Jelsma T, Maaskant-Van Wijk PA, Van der Schoot CE, Van Zwieten D, Roos D, Den Dunnen JT, De Haas M: Rapid genotyping of blood group antigens by multiplex polymerase chain reaction and DNA microarray hybridization. Transfusion 2005:45:667-679.

11 Avent ND, Martinez A, Flegel WA: The BloodGen project: toward mass-scale comprehensive genotyping of blood donors in the European Union and beyond. Transfusion 2007;47(suppl 1):40S-46S.
12 Karpasitou K, Drago F, Crespiatico L, Paccapelo C, Truglio F, Frison S, Scalamogna M, Poli F: Blood group genotyping for $\mathrm{Jk}^{\mathrm{a}} / \mathrm{Jk}^{\mathrm{b}}, \mathrm{Fy}^{\mathrm{a}} / \mathrm{Fy}^{\mathrm{b}}, \mathrm{S} / \mathrm{s}, \mathrm{K} / \mathrm{k}, \mathrm{Kp}^{\mathrm{a}}$ / $\mathrm{Kp}^{\mathrm{b}}, \mathrm{Js}^{\mathrm{a}} / \mathrm{Js}^{\mathrm{b}}, \mathrm{Co}^{\mathrm{a}} / \mathrm{Co}^{\mathrm{b}}$, and $\mathrm{Lu}^{\mathrm{a}} / \mathrm{Lu}^{\mathrm{b}}$ with microarray beats. Transfusion 2008:48:505-512.

13 Polin H, Danzer M, Pröll J, Hofer K, Heilinger U, Zopf A, Gabriel C: Introduction of a real-time based blood group genotyping approach. Vox Sang 2008; 95:125-130.

14 Daniels G: Human Blood Groups, 2nd ed. Oxford, Blackwell Science, 2002.

15 Tournamille C, Colin Y, Catron JP, Le Van Kim C: Disruption of a GATA motif in the Duffy gene promoter abolishes erythroid gene expression in Duffynegative individuals. Nat Genet 1995;10:224-228.

16 Taliano V, Guévin R-M, Tippett P: The genetics of a dominant inhibitor of the Lutheran antigens. Vox Sang 1973;24:42-47.

17 Karamatic Crew V, Mallinson G, Green C, Poole J, Uchikawa M, Tani Y, Geisen C, Oldenburg J, Daniels G: Different inactivating mutations in the LU genes of three individuals with the Lutheran-null phenotype. Transfusion 2007;47:492-498.

18 Norman PC, Tippett P, Beal RW: An Lu(a-b-) phenotype caused by an $\mathrm{X}$-linked recessive gene. Vox Sang1986;51:49-52.

19 Mulley JC, Norman PC, Tippett P, Beal RW: A regional localisation for an $\mathrm{X}$-linked suppressor gene (XS) for the Lutheran blood group. Hum Genet 1988;78:127-129.

20 Huang CH, Johe K, Moulds JJ, Siebert PD, Fukuda M, Blumenfeld OO: Delta glycophorin (glycophorin B) gene deletion in two individuals homozygous for the S--s--U-- blood group phenotype. Blood 1987;70:1830-1835.

21 Lee S: The value of DNA analysis for antigens of the Kell and the Kx blood group systems. Transfusion 2007;47(suppl 1):32S-39S.

22 Lee S, Russo DC, Reiner AP, Lee JH, Sy MY, Telen MJ, Judd WJ, Simon P, Rodrigues MJ, Chabert T, Poole J, Jovanovic-Srzentic S, Levene C, Yahalom V, Redman CM: Molecular defects underlying the Kell null phenotype. J Biol Chem 2001;276:27281-27289.
3 Wester ES, Storry JR, Schneider K, Nilsson Sojka B, Poole J, Olsson ML: Genetic basis of the K(0) phenotype in the Swedish population. Transfusion. 2005;45:545-549.

24 Körmöczi GF, Wagner T, Jungbauer C, Vadon M, Ahrens N, Moll W, Mühlbacher A, Ozgül-Gülce S, Kleinrath T, Kilga-Nogler S, Schönitzer D, Gassner C: Genetic diversity of KELnull and KELel: a nationwide Austrian survey. Transfusion 2007;47: 703-714.

25 Castilho L: The value of DNA analysis for antigens in the Duffy blood group system. Transfusion 2007;47(suppl 1):28S-31S.

26 Steffensen R. Carlier K, Wiels J, Levery SB, Stroud M, Cedergren B, Nilsson Sojka B, Bennett EP, Jersild $\mathrm{C}$, Clausen $\mathrm{H}$ : Cloning and expression of the histo-blood group Pk UDP-galactose: Ga1beta4G1cbeta1-cer alpha1, 4-galactosyltransferase. Molecular genetic basis of the p phenotype. J Biol Chem 2000;275:16723-16729.

27 Furukawa K, Iwamura K, Uchikawa M, Sojka BN, Wiels J, Okajima T, Urano T, Furukawa K: Molecular basis for the $\mathrm{p}$ phenotype. Identification of distinct and multiple mutations in the alpha 1,4-galactosyltransferase gene in Swedish and Japanese individuals. J Biol Chem 2000;275:16752-16756.

28 Koda Y, Soejima M, Sato H, Maeda Y, Kimura H: Three-base deletion and one-base insertion of the alpha $(1,4)$ galactosyltransferase gene responsible for the P phenotype. Transfusion 2002;42:48-51.

29 Hellberg A, Chester MA, Olsson ML: Two previously proposed P1/P2-differentiating and nine novel polymorphisms at the A4GALT (Pk) locus do not correlate with the presence of the P1 blood group antigen. BMC Genet 2005;6:49.

30 Daniels G, Van der Schoot CE, Olsson ML: Report on the Second International Workshop on molecular blood group genotyping. Vox Sang 2007;93 83-88. 